\title{
Surveillance of Barley Yellow Dwarf Virus (BYDV) in All Barley Growing Areas of Ethiopia
}

\author{
Nahom Weldu Abraha* \\ Plant Pathology Assistant Researcher, Axum Agricultural Research Center, Tigray Agricultural Research Institute, P.O. \\ Box 230, Axum, Ethiopia
}

*Corresponding Author

Nahom Weldu Abraha

\section{Article History}

Received: 12.06 .2020

Accepted: 22.06 .2020

Published: 25.06.2020

\begin{abstract}
Barley (Hordeum vulgare L.) is the major crop for large numbers of people living in the cooler semi-arid areas of the world. The crop grow in the high lands of Ethiopia that ranges 2000-3000 m.a.s.l and covers approximately about $6.42 \%$ the shares of total area covered. Barley yellow dwarf virus (BYDV) is the most widely distributed and most destructive virus on cereal crops in the world. The virus is transmitted by several species of aphids in a persistent manner including Rhopalosiphum padi, which is the most efficient once. There are also species of aphids such as Schizaphis graminum, Macrosiphum avenae, R.maidis were also reported as vectoring the virus. It affects a wide variety of gramineous hosts, including barley, oats, wheat, rye, and many lawn, weed, pasture and range grasses. Barley yellow dwarf affects plants by causing stunting growth, reduced tillering, suppressed heading, sterility and failure to fill the kernels. Five BYDV causing strains of virus were identified in Ethiopia although their distribution varies from area to area these are (BYDV-SGV, BYDV-PAV, BYDV-MAV, BYDV-RPV, and BYDV-RMV). BYDVs can have a serious impact on an important limiting factor for grain production where ever barley is grown and the average yield losses attributable to natural BYDV infection can range between11 and 33\%. Barley yellow virus disease on barley in Ethiopia was first reported in 1967 regardless of the barley yellow dwarf disease strain(s) or species responsible .This report was based on only symptomology and was not confirmed by any standard laboratory diagnostic methods. The survey conducted on BYDV tries to cover almost all barley growing zones of Ethiopia and the distribution of BYDV was clearly identified under eight barley growing administrative zones of Ethiopia.
\end{abstract}

Keywords: Barley and Barley yellow dwarf virus.

\section{INTRODUCTION}

Barley (Hordeum vulgare L.) is a major crop for large numbers of people living in the cooler semi-arid areas of the world. In tropical Africa Ethiopia is the only country where barley is a major crop being the fifth most important crop both in area under cultivation and in production after teff, maize, sorghum and wheat. It is grown mainly in the highlands of the country and represents approximately around $6.42 \%$ of the total area where crops grown (CSA, 2018/2019).

It is predominantly grown at altitudes ranging from 2000 to 3000 m.a.s.1 in various regions of the country. Barley is produced in both the main and short rainy season. It is preferred by subsistence farmers because of its ability to grow on marginal farms unlike other cereals. Traditionally barley is cultivated under no or little external inputs such as fertilizer or chemicals to control the major pests. Barley has a wide range of uses. Its grain is used as a staple food for malting and for making local drinks and is sold for cash. Its straw and stem stubs are used for animal feed and thatching. The annual average national productivity of the crop is 2.17712000 ton/ha (CSA, 2018/19). At this time production of barley in Ethiopia like other cereals is challenging by both biotic and abiotic factors and out of these, barley yellow dwarf virus is one of the biotic factors of barley production constraints in Ethiopia.

Copyright @ 2020: This is an open-access article distributed under the terms of the Creative Commons Attribution license which permits unrestricted use, distribution, and reproduction in any medium for non commercial use (NonCommercial, or CC-BY-NC) provided the original author and source are credited. 
Barley yellow dwarf virus (BYDV) a species of luteovirus group which is the most widely distributed and most destructive virus on cereal crops in the world [1-3].This disease can affect other cereals like wheat, oat and rye but the Symptoms in Triticum aestivum were not always clear and characterized by stunting growth with yield losses [4].

On oat the symptoms is yellowish green blotches near the leaf tip and these blotches enlarge, merge and turn to red, purple, brown, or yellow orange. The yellowish green area extended to the lower parts of the leaf and the leaves may curl inward [5].

In Hordium vulgare the most characteristic symptoms are dwarfing with brilliant yellow color on the leaves which extends from the tip toward the basal parts .BYDV cause dwarfing with yellowing or reddening on leaves [6].The virus is transmitted by several species of aphids in a persistent manner including Rhopalosiphum padi, which is the most efficient. Other species of aphids such as Schizaphis graminum, Macrosiphum avenae, R.maidis were also reported vectoring the virus. The aphids can acquire the virus by feeding on a diseased plant for a minimum of $30 \mathrm{~min}$ and the viruliferous aphids are capable of transmitting the virus after an incubation period of 12 hrs to 4 days. The virus is not transmitted by eggs and does not replicate in the vector.

\section{OBJECTIVES}

To develop scientific pepper reviewing techniques

To review studies conducted on BYDV

\section{Litrature REVIEW \\ Host ranges}

Barley yellow dwarf viruses occurs throughout the world and It affects a wide variety of gramineous families including barley, oats, wheat, rye, and many lawn, weed, pasture and range grasses. Barley yellow dwarf affects plants by causing stunting, reduced tillering, suppressed heading, sterility and failure to fill the kernels. In some cases entire fields are destroyed and the crops are not worth harvesting. Out of the main host crops oats is the most severely affected and suffers serious losses annually. In years of barley yellow dwarf outbreaks oat yield losses may range from 30 to50\% while barley and wheat losses range between 5 and $30 \%$.In addition to these quantitative losses there was also a quality losses of the grain and losses in forage crops from the resulting failure or reduced productivity of pasture, range, and meadow grasses.

\section{Strains of virus caused BYDV}

Barley yellow dwarf (BYDV) disease caused by a group of luteovirus collectively known as Barley yellow dwarf viruses (BYDVs) is economically damaging and the most widespread disease of cereals crops worldwide [7]. Severely infected crops often produce no grain. Based on the principal aphid species that transmit different isolates of BYDV. Rochow [8] characterized and designated five strains of the virus (BYDV-PAV, BYDV-MAV, BYDV-RPV, BYDV-RMV and BYDV-SGV). More recently the International Committee on Taxonomy of Viruses (ICTV) accepted the five barley yellow dwarf virus strains as distinct species in the family Luteoviridae [9].

The species BYDV-PAV and BYDV-MAV were placed in the genus Luteovirus and BYDV-RPV was renamed as Cereal yellow dwarf virus (CYDV-RPV) and placed in the genus Polerovirus. The other two species, BYDV-RMV and BYDV-SGV have yet to be assigned to a genus based on the recent classification by ICTV [8].

\section{Economic Importance}

BYDVs have a serious impact on and an important limiting factor for grain production where ever cereals are grown. However, global yield losses due to the BYDVs are difficult to estimate because of insufficient information. Average yield losses attributable to natural BYDV infection can range between11 and 33\% [1] in some areas the losses were reported to reach up to $86 \%$. The relationship between the disease incidence and yield loss was found to be linear in wheat and oats. A $1 \%$ increase in BYD disease incidence caused yield reduction to increase from 20 to $50 \mathrm{~kg} / \mathrm{ha}$ in wheat and from 30 to $60 \mathrm{~kg} / \mathrm{ha}$ in oats (F Nutter, un published and [10]. calculated that hypothetical $5 \%$ losses caused by BYDVs in the United States in 1989 would result in crop losses valued at $\$ 847.0$ million for corn, $\$ 387.1$ million for wheat, $\$ 48.5$ million for barley, and $\$ 28.0$ million for oats. A PAV-like virus may also cause sugarcane yellow leaf disease in Brazil, Hawaii, and Australia [11]. Thus the range of economically important crops affected by BYDVs may be greater than previously thought.

\section{METHOD OF TRANSMISSION}

BYDV is transmitted into barley and wheat fields by vector of winged aphids. These flights of winged aphids can occur at a time when the weather is warm enough. When virus-carrying aphids land in a field, it starts to feed on plants and transmit the viruses in the process. This is a primary infection and the aphid offspring that feed on these 
primary infected plants will acquire the virus. When these aphids move from plant to plant they spread the viruses and this is referred to as secondary infection. Most of the aphids that cause secondary spread are wingless and spread the infection to neighboring plants in the field. Winged aphids that develop on the primary infected plants can also cause secondary spread of BYDV. Aphids that infect the crop in the field transmit the viruses when plants are in an early stage of development. This early infection is more damaging than infections in the mature crops.

In cold season the viruses are likely to be spread only by wingless aphids and movement is limited to neighboring plants, resulting in the bowl-shaped depressions. Aphids are small insects with soft, pear-shaped bodies and piercing sucking mouthparts. Once aphids found a suitable host they tend to remain on that plant reproducing and forming large colonies. Different aphid species can be identified by four structures i.e. the antennae, the feet (tarsi), the knee (joint between two segments of the leg), and the "tail pipes" (cornicles, which are used to secrete alarm chemicals). Aphid movement can be categorized as flying, flitting, or walking. Each type benefits the aphid in specific ways and also results in a characteristic spatial pattern of BYDV. Most adult aphids in a colony are wingless but a small number in each generation has wings to allow for continual population migration to new host plants.

Environmental factors such as poor weather, overcrowding, and reduction in food quality cause more aphids to develop wings allowing movement away from unfavorable local conditions. Large populations of winged aphids can travel hundreds of miles in prevailing winds and storm cells. Little is known about the impact of these long-distance immigrants. Locally individual winged aphids can move from one field to another or from a weed host to a crop field. In the field crop aphids move from drying summer grasses to young fall grasses, including small grains which may introduce BYDV in to crop fields. Some aphids will make short flights (flitting) a few feet to a few meters which allow the viruses to move to new spots within a field. Aphids often walk from plant to plant. This gradually expands the area of an existing population and produces near-circular spots of infected plants. The plants infected earliest are near the center and the most recently infected ones are near the edges. The spots expand in size over time.

Aphid life cycles are complicated and vary considerably among species, climatic regions, and even between individual populations of the same species. Within the wheat fields, most of the aphids are females that do not need to mate before producing offspring. These aphids give birth to live offspring baby aphids instead of eggs. Some times when there were unfavorable conditions exists aphids overwinter as juveniles and adults but they overwinter as eggs in northern areas of the United States. Temperature determines the extent of winter survival of juveniles and adults. In general the warmer the temperature the more aphids can survive, move, and reproduce. Conversely colder temperatures result in lower survival rates, fewer offspring, and less movement. As a rule of thumb, it needs to be about 50 degrees $\mathrm{F}$ for aphids to be active; temperatures below 30 degrees $\mathrm{F}$ result in increased aphid mortality. However, some aphids survive even at very low temperatures. A warm dry winter aids aphid survival and virus spread whereas a cold, wet winter reduces aphid survival and movement.

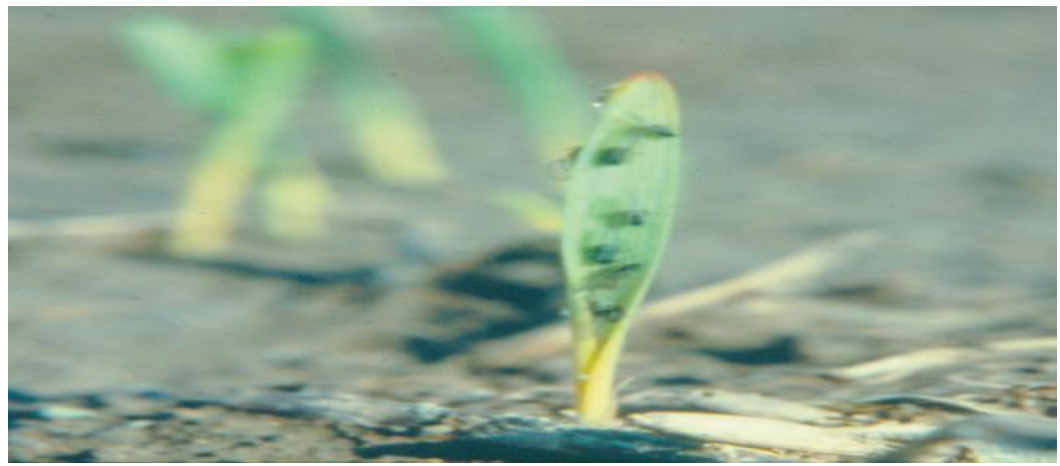

Fig-1: Winged aphids colonize the small grain as soon as it emerges

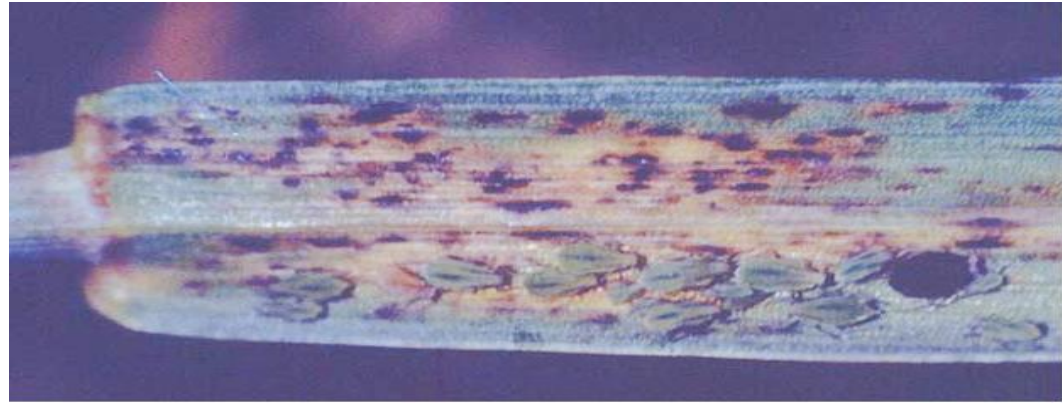

Fig-2: Direct feeding damage by the green bug on wheat and the leave becomes discolored 


\section{Distribution BYDV in Ethiopia}

As for other crop the formal research on virus diseases of barley in Ethiopia dates back about 15 years. Since the first report of BYDV in Ethiopia by Stewart and Dagnachew Yirgu was in 1967.All research activities reported until 1989 were based on either field visual observations or only small sample sizes and few locations [12, 13].

The information generated was scanty inconclusive and unrepresentative. This paper reviews research results from systematic intensive and representative surveys on the occurrence and distribution of BYDVs and in the major barley growing areas; the impact of the dominant BYDV species (BYDVPAV)on the yield and growth of barley.

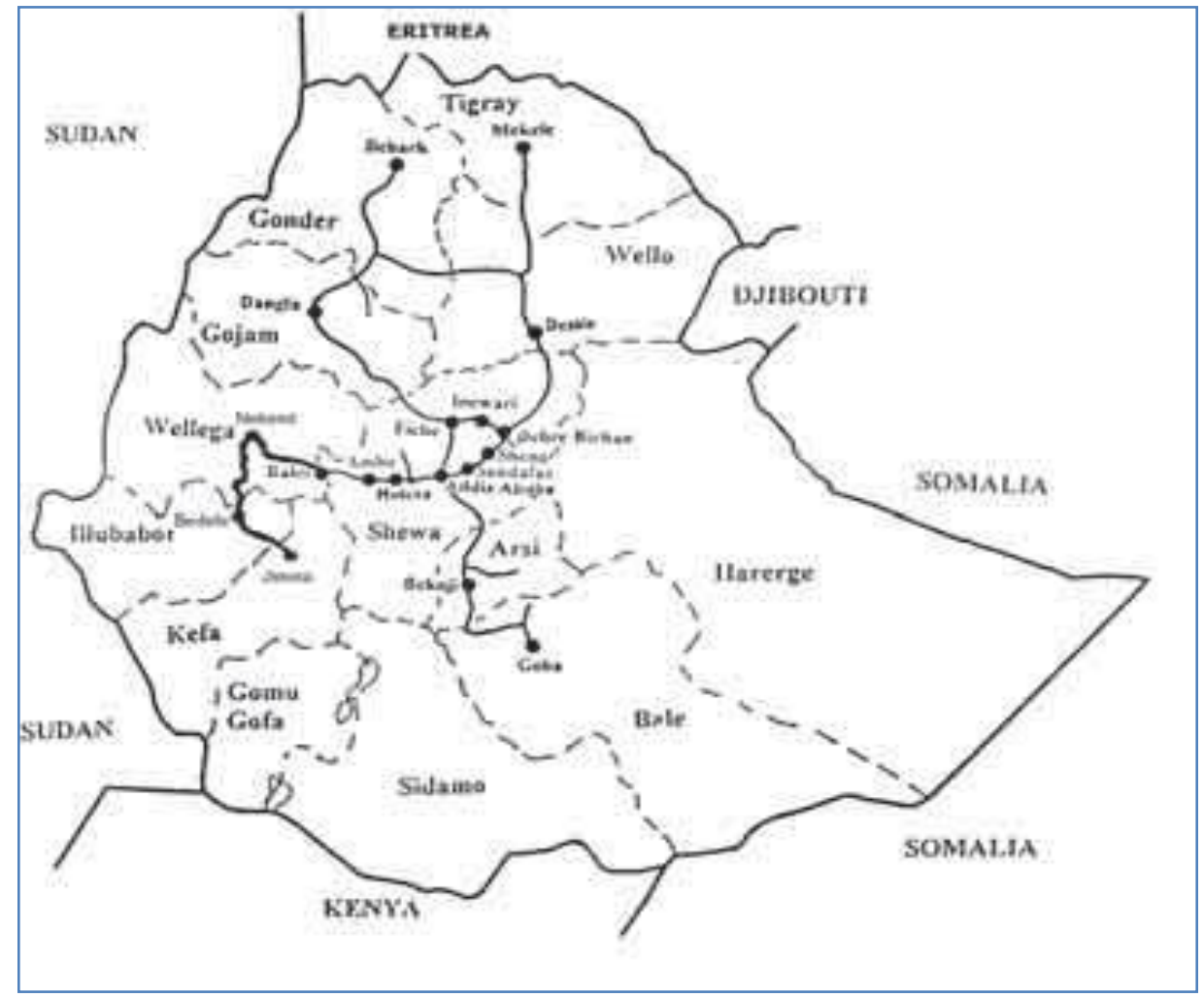

Fig-3: Map showing BYDV surveyed areas and routes in Ethiopia

Barley yellow dwarf virus disease on barley in Ethiopia was first reported by Stewart and Dagnachew Yirgu [14], regardless of the barley yellow dwarf disease strain(s) or species responsible .This report was based on only symptomology and was not confirmed by any standard laboratory diagnostic methods suggested for BYDV(i.e. biological ,serological or molecular means ) Subsequent survey was conducted using serological diagnostic method carried out in 1984-1989 by both national and foreign researchers. These studies was confirmed the occurrences of only BYDV-PAV and BYDV-MAV in barley but covered only a few growing area. More over the surveys had very small sample size were scattered not representative and inclusive? They were reviewed by [15, 16]. Results of systematic comprehensive and representative survey conducted in 1994-2001 during both main and short rain seasons.

Table-1: Survey result of BYDV at Arisi zone

\begin{tabular}{|c|c|c|c|c|c|c|c|c|}
\hline \multirow[t]{2}{*}{ Zone District } & \multirow{2}{*}{$\begin{array}{l}\text { Fields } \\
\text { Surveyed }\end{array}$} & \multirow[t]{2}{*}{ Sample tested } & \multicolumn{6}{|c|}{ No. of samples tested positive for serotype } \\
\hline & & & PAV & MAV & RPV & RMV & SEV & Mixed \\
\hline \multicolumn{9}{|l|}{ Arisi } \\
\hline Bekoji & 13 & 325 & $15(8)$ & $10(4)$ & $8(3)$ & $4(3)$ & $10(7)$ & $7(7)$ \\
\hline Asasa & 10 & 250 & $7(5)$ & $4(4)$ & $4(3)$ & $3(3)$ & $8(3)$ & $4(4)$ \\
\hline Kofale & 4 & 100 & 0 & $4(2)$ & 0 & $1(1)$ & 0 & 0 \\
\hline Sagure & 1 & 25 & 0 & 0 & 0 & 0 & 0 & 0 \\
\hline Assela & 3 & 75 & 0 & 0 & 0 & $1(1)$ & 0 & 0 \\
\hline Iteya & 3 & 75 & 0 & 0 & 0 & 0 & 0 & 0 \\
\hline Dera & 1 & 25 & 0 & 0 & 0 & 0 & 0 & 0 \\
\hline Sub tatal & 35 & 875 & $22(13)$ & $18(10)$ & $12(6)$ & $9(8)$ & $18(10)$ & $11(11)$ \\
\hline
\end{tabular}


Table-2: Survey result of BYDV at North Shewa Amhara zone

\begin{tabular}{|l|l|l|l|l|l|l|l|l|l|}
\hline Zone District & Fields & Sample tested & \multicolumn{6}{|l|}{ No. of samples tested positive for serotype } \\
\cline { 3 - 9 } & Surveyed & & PAV & MAV & RPV & RMV & SEV & Mixed \\
\hline Northshewa (Amhara region) & & \multicolumn{7}{|l|}{$\mid$} \\
\hline Ensaro & 4 & 100 & 0 & $2(1)$ & $1(1)$ & 0 & 0 & 0 \\
\hline Inewarl & 1 & 25 & 0 & 0 & 0 & 0 & 0 & 0 \\
\hline D/brhan & 6 & 150 & 0 & $8(4)$ & $3(2)$ & 0 & 0 & $1(1)$ \\
\hline Angola & 10 & 250 & $5(4)$ & $4(3)$ & 0 & 0 & $2(1)$ & 0 \\
\hline Sub total & 21 & 525 & $5(4)$ & $14(8)$ & $4(3)$ & 0 & $2(1)$ & $1(1)$ \\
\hline
\end{tabular}

Table-3: Survey result of BYDV at North Shewa Oromia zone

\begin{tabular}{|c|c|c|c|c|c|c|c|c|}
\hline \multirow[t]{2}{*}{ Zone District } & \multirow{2}{*}{$\begin{array}{l}\text { Fields } \\
\text { Surveyed }\end{array}$} & \multirow[t]{2}{*}{ Sample tested } & \multicolumn{6}{|c|}{ No. of samples tested positive for serotype } \\
\hline & & & PAV & MAV & RPV & RMV & SEV & Mixed \\
\hline \multicolumn{9}{|c|}{ North shewa (oromia region ) } \\
\hline Chancho & 8 & 200 & 0 & 0 & $4(3)$ & 0 & 0 & 0 \\
\hline YayuGulale & 3 & 75 & 0 & 0 & 0 & 0 & 0 & 0 \\
\hline Hambiso & 4 & 100 & 0 & 0 & 0 & 0 & 0 & 0 \\
\hline Muketurl & 6 & 150 & 0 & 0 & $2(2)$ & 0 & 0 & 0 \\
\hline Mendida & 1 & 25 & 0 & 0 & 0 & 0 & 0 & 0 \\
\hline Shemo & 1 & 25 & 0 & $1(1)$ & 0 & 0 & 0 & 0 \\
\hline Sendafa & 1 & 25 & 0 & 0 & 0 & 0 & 0 & 0 \\
\hline Sub total & 24 & 600 & 0 & $1(1)$ & $6(5)$ & 0 & 0 & 0 \\
\hline
\end{tabular}

Table-4: Survey result of BYDV at West Shewa zone

\begin{tabular}{|c|c|c|c|c|c|c|c|c|}
\hline \multirow[t]{2}{*}{ Zone/ District } & \multirow{2}{*}{$\begin{array}{l}\text { Fields } \\
\text { Surveyed }\end{array}$} & \multirow[t]{2}{*}{ Sample tested } & \multicolumn{6}{|c|}{ No. of samples tested positive for serotype } \\
\hline & & & PAV & MAV & RPV & RMV & SEV & Mixed \\
\hline \multicolumn{9}{|l|}{ West shewa } \\
\hline Holetta & 4 & 100 & $3(2)$ & $1(1)$ & 0 & 0 & 0 & $1(1)$ \\
\hline Ginchi & 9 & 225 & $2(1)$ & $4(2)$ & $1(1)$ & $1(1)$ & $1(1)$ & $1(1)$ \\
\hline Ambo & 3 & 75 & 0 & $2(1)$ & 0 & 0 & 0 & 0 \\
\hline Jelidu & 2 & 50 & $2(1)$ & $2(1)$ & $2(1)$ & 0 & 0 & $1(1)$ \\
\hline Gedo & 7 & 175 & $1(1)$ & $2(1)$ & 0 & $2(1)$ & $2(1)$ & $2(2)$ \\
\hline Chiltu & 7 & 175 & $3(2)$ & $3(3)$ & $3(2)$ & $2(2)$ & $2(2)$ & $4(4)$ \\
\hline Tikur & 1 & 25 & $2(1)$ & 0 & 0 & 0 & 0 & 0 \\
\hline Sub total & 33 & 825 & $13(8)$ & $14(9)$ & $6(4)$ & $5(4)$ & $11(7)$ & $9(9)$ \\
\hline Grand total & 113 & 2825 & $40(25)$ & $47(28)$ & $28(18)$ & $14(12)$ & $31(18)$ & $21(21)$ \\
\hline
\end{tabular}

The survey conducted on BYDV tries to cover almost all barley growing zones of Ethiopia and the distribution of BYDV was also clearly identified. Based on the survey result conducted by researchers on BYDV the result indicted that distribution was in almost all of the barley growing area of the country even though there was some variation among the surveyed area.

There were sever BYDV symptoms and epidemics in barley fields of west Shewa during the Meher season of 1994.Based on the Tissue immunoassay (TBIA) conducted by [17] indicated that BYDV was present in 19 of 25 locations $(76 \%)$ surveyed and disease incidence was up to $40 \%$ in some locations [18]. Eight barley growing administrative zones from Ethiopia (Arisi, North Shewa Amhara, North Shewa Oromia, west Shewa,Gojam,Gonder, wollo and Southern Zone of Tigray ) were surveyed. The result of the survey indicated that there was disease symptom in Arsi typical of BYDV such as yellowing and stunting were common at higher altitudes particularly>2500 m.a.s.1. BYDV was occurred ether in single or mixed infection detected in 23 to 35 barley fields surveyed in this zone . All five BYDV causing species were detected in Arsi zone. The result of the survey shows the dominance of species detected that is BYDV-PAV (27.8\%) followed by BYDV-MAV and BYDV-SGV (each 22.8\%) CYDV-RPV (15.2\%) and BYDV-RMV $(11.4 \%)$. There were mixed infections of two or more species in some of the surveyed area .In North Shewa Zone of the Amhara region, of 21 fields surveyed in four districts, BYDVs were detected in 12 (57.1\%) fields at 2550-2800 m.a.s.1. In this zone all BYDV species were detected except BYDV-RMV. The most wide spread type in North Shewa was BYDV-MAV (57.7\%) followed by BYDV-PAV (19.2\%) and BYDV-SGV (7.7\%). 
In North Shewa Zone of the Oromia region of 24 fields was surveyed in seven districts the disease was identified in samples from only five (20.8\%) fields in three districts. Only BYDV-MAV was most common and similarly in West Shewa Zone BYDV was detected in 14 of 33 fields (42.4\%) of the surveyed seven districts either in single or mixed infections. The BYDV-MAV type was most common (28.5\%) in West Shewa, followed by BYDV-PAV (26.5\%), BYDV-SGV (22.4\%) BYDV-RPV (12.2\%) and BYDV-RMV (10.4\%). There were mixed infections of two or more types in nine samples [18].

In Gojam BYDV-PAV and BYDV-SGV were not detected in any samples however TBIA indicated BYDVMAV and BYD-RMV in three of the 13 fields surveyed (23.1\%) were found. BYDV-MAV was identified from only two samples in one location and BYDV-RMV from 10 samples in two locations. In Gonder the three species (BYDV-PAV, BYDV-MAV, and -BYDV-RMV) were detected in $27 \%$ of fields of the study area. In Wollo three spices BYDVs (BYDV-PAV, BYDV-MAV and BYDV-RPV) were identified from seven samples of three locations. There was mixed infection of two types (BYDV-PAV and BYDV-SGV) in some of the samples taken from Dilba area of Guba Lafto District in North Wollo. In the southern zone of Tigray Regional State however only BYDV-PAV was detected in one sample collected from Maychew area [18-20].This survey result indicates that BYDV is distributed in almost all barley growing areas of the country.

\section{Life cycle}

Barley yellow dwarf viruses become much more important and wide spread with the increase in early drilling of winter cereals. The viruses exists as several strain and is transmitted by various species of cereal aphids . Direct transfer by wing less aphids living on grass or on volunteer cereals which survive cultivation and move through the soil colonizing the host plant this cycle of aphids helps to increase their number from time to time.

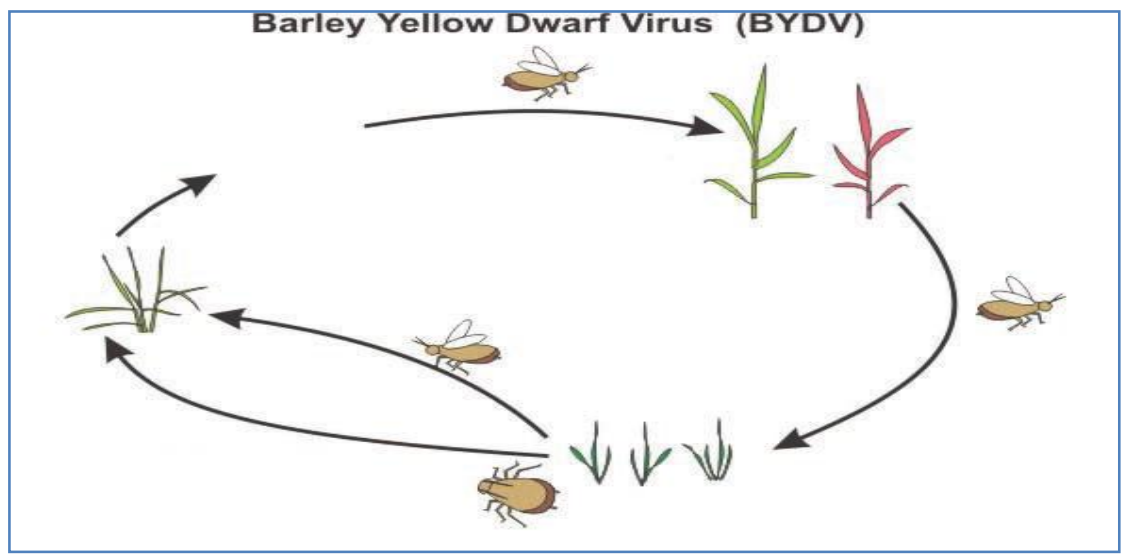

Fig-4: Aphid transmission of BYD virus

\section{Disease Symptoms}

Symptoms of BYDV infection include leaf discoloration, stiffening or curling of leaves, death of leaf tissue, stunting of the plants, reduced tillering, and even plant death. Leaf discolorations can range from yellow in barley, rye, and wheat to orange or tan, to red or purple in oats and wheat. Leaf discoloration begins at the tip and progresses down to the base of the leaf. On a field scale, the formation of numerous bowl-shaped depressions about 3 to 8 feet in diameter are another symptom of YDV infection .This "field signature" is especially visible at flowering. Infected plants in the center of depressions are stunted and tend to have severe leaf discoloration. Plants toward the perimeter of the patches show less stunting and leaf discoloration. Research in Virginia has shown that these stunted areas yield about 30 percent less grain than non stunted areas.

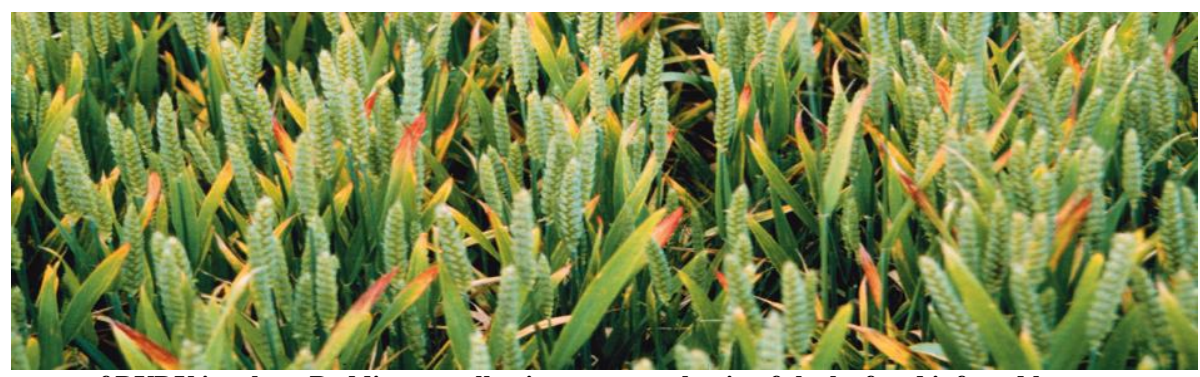

Fig-5: Symptoms of BYDV in wheat Redding or yellowing starts at the tip of the leaf and infected leaves are usually twisted 


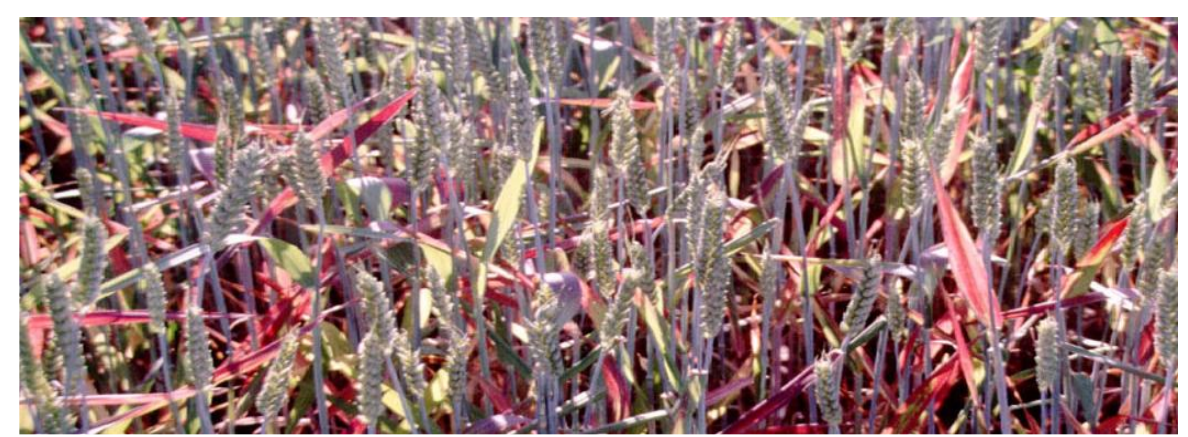

Fig-6: As the Virus infection progress the entire leaves are become discolored and may die prematurely

\section{BYDV Management Strategies}

There are three major primary management tactics to minimize yield losses due to BYD, but none of them gives 100 percent control. Under the right conditions a very small number of aphids can have a major impact on BYD incidence and crop yield losses. It would be easier to manage BYD if the proportion of invading aphids carrying YDV in a given year was known, but this cannot be easily determined.

\section{Planting time of the host crop}

The first and the most effective technique is avoid early planting research output shows that fields planted later in the fall have lower aphid populations which take longer to grow and spread than do earlier planted fields. Delaying planting until the first hard freeze which kills many soft-bodied insects including aphids leaves fewer aphids to fly into crop fields. In addition temperatures are generally cool enough to greatly reduce movement and reproduction of the aphids that do arrive in the field.

\section{Using insecticide chemicals}

There are different types of insecticide for different insect pests and imidacloprid (Gaucho, Gaucho XT) and thiomethoxam (Cruiser) are the recommended insecticide for aphids management applied as a seed treatment to reduce BYD incidence and result in significantly higher wheat yields than wheat not treated with insecticides .These insecticides have been shown to be effective up to 90 days after planting. There are also foliar insecticides that we can use for the management of aphids and reduce incidence of BYD like organophosphate insecticides that kill aphids but do not effectively suppress BYD whereas pyrethroid insecticides control aphids and are usually effective at suppressing BYD. The most important time for controlling aphids varies from area to area and researches from in Virginia says spraying any time in autumn between the 2-leaf stages and tillering has been shown to be the best time to control aphids.

\section{Using resistant varieties}

The third management tactic is to select barely variety that is less susceptible to BYDV infection. Currently there are no commercial varieties which are resistant and variety selection is not recommended to control BYD but at this time several resistance genes have been identified that reduce virus levels in the plant. In the future plant resistance is likely to become an important part of the BYD control program.

\section{REFERENCE}

1. Lister, R.M. and Ranieri R. (1995). Distribution and economic importance of barley yellow dwarf. pp. 29-53. In: Barley yellow dwarf.

2. Miller, G. H. (2002). U.S. Patent No. 6,475,139. Washington, DC: U.S. Patent and Trademark Office.

3. Kennedy, T. F., \& Connery, J. (2005). Grain yield reductions in spring barley due to barley yellow dwarf virus and aphid feeding. Irish journal of agricultural and food research, 111-128.

4. Irwin M.E., and Thresh J.M. (1990). Epidemiology of barley yellow dwarf: A study of ecological complexity. Annual Review of Phytopathology.

5. D’Arcy, C.J. (1995). Symptomatology and host range of barley yellow dwarf. Journal of Plant Pathology. D’Arcy, C.J. and P.A. Bumeft (edited). The American Phyto pathological Society. St. Paul. MN.

6. Rochow, W.F., Sward, R.J. and Waterhouse, P.M. (1996). Barley yellow dwarf luteoviruses. Journal General Virology.

7. Burnett, P.A. (1984). Preface. in:P.A. Burnett (edited). World Perspectives on Barley Yellow Dwarf. Proceedings of a Workshop. CIMMYT, Mexico.

8. Rochow, W.F. (1970). Barley yellow dwarf virus: phenotypic mixing and vector specificity. Science.

9. van Regenmortel, M. H., Fauquet, C. M., Bishop, D. H., Carstens, E. B., Estes, M. K., Lemon, S. M., ... \& Wickner, R. B. (2000). Virus taxonomy: classification and nomenclature of viruses. Seventh report of the International Committee on Taxonomy of Viruses. Academic Press. 
10. Hewing,s A.D., Eastman C.E. (1995). Epidemiology of barley yellow dwarf in North America. See Ref.

11. Vega, J, Scagliusi, S.M.M., Ulian, E.C. (1997). Sugarcane yellow leaf disease in Brazil: evidence of association with aluteovirus. Plant Disease

12. Agranovsky, A.A.(1986). Barley Yellow Dwarf in central Ethiopia in 1984/85 and 1985/86crop seasons. pp 56-60, in: Proceedings of the 11th Annual Meeting of Ethiopian Phytopathological Committee (EPC), 6-7 February 1986. Holetta, Ethiopia.

13. Dereje, T., Paul, Y.S., Berhanu B., Amare A. and Burnett, P.A. (1993). Survey of barley yellow dwarf virus in south eastern Ethiopia. In: Proceedings of the Join conference of the Ethiopian Phytopathological Committee and the Committee of

14. Hundie, B., Woldeab, G., Taddese, K., Belete, E., \& Bekele, B. (2011). Achievements of research on barley Smuts, Ergot and Root and Foot Rot diseases in Ethiopia. Barley Research and Development in Ethiopia, 273.

15. Eshetu B. (1986). A review of research on disease of barley, teff and wheat in Ethiopia.pp 79-108, in: Tsedeke Abate (edited). Proceedings of the review of crop protection research in Ethiopia. Institute of Agricultural Research, 4-7 February 1985, Addis Ababa , Ethiopia. Addis Ababa, Ethiopia.Ethiopian Entomologists, 5-6 March 1992, Addis Ababa. CPSE, Addis Ababa, Ethiopia.

16. Hailu, G. and VanLeur, J.A.G. (edite). (1996). Barley Research in Ethiopia: Past work and Future Prospects. Proceedings of the 1st Barley Research Review Workshop, 16-19 October 1993, Addis Ababa. IAR /ICARDA, Addis Ababa, Ethiopia.

17. Berhanu B, Abdulrazak Y, Alemu L, Mih, A.M., Makkouk, K.M. \& Getaneh W. (1995). Barley yellow dwarf virus in Western Shewa highlands. Annual Report. Nile Valley and Red Sea Regional Programme on Cool-season Food Legumes and Cereals. Regional Networks. ICARDA/NVRSRP, Cairo, Egypt.

18. Berhanu B. and Makkouk, K.M. (2003). Status of barley yellow dwarf and cereal yellow dwarf viruses infecting barley in Ethiopia. Pest Management Journal of Ethiopia, 7: 29-40.

19. El-Zoubi, M., Almosa, A. and Skaria M. (1992). Studies on BYDV in cereal crop in Jordan. In: BYDV in west Asiaand North Africa. Comeau, A. and K. Makkouk (edited). Sayce Publishing, Exeter, UK.

20. Halberd, S.E., Connelly, B.J., Lister R.M., Klein R.E. and Bishop G.W. (1992). Vector specificity of Barley yellow dwarf virus serotypes variants in southwestern Idaho. Ann. Appl. Biol. 